\title{
A organização e a atividade das associações voluntárias de socorro mútuo de trabalhadores de Florianópolis - SC (1886-1932)
}

Rafaela Leuchtenberger

Resumo: O presente artigo tem como objetivo apresentar quais eram e como se organizavam as associações voluntárias de socorro mútuo de trabalhadores em Florianópolis - SC, entre os anos de 1886 e 1932 . Inicialmente, realiza-se um mapeamento dessas associações passando então para uma análise de suas formas de organização e uma busca por compreender quem eram as pessoas que se associavam a estas instituições e o que buscavam.

Palavras-chave: Associativismo; Trabalhadores; Florianópolis.

Abstract: This article aims to present a description of the voluntary mutual aid associations of workers in Florianópolis - SC between the years 1886 and 1932, focusing on what they were and their forms of organization. Initially, there will be a mapping of those associations and then passing to an analysis of their ways of structuring, as well an attempt to understand who were the workers associated to those institutions and what they used to seek from them.

Keywords: Mutualism; Working class; Florianópolis.

Na entrada do século $X X$, nota-se a existência e o surgimento de diferentes espaços de sociabilidade na cidade de Florianópolis, fenômeno que acompanhava o ritmo de crescimento e desenvolvimento pelo qual a cidade estava passando. Diversos tipos de organizações com base na estrutura associativa se constituíam, certamente por ser esta a forma mais viável e difundida, dentro da institucionalidade, de se organizar interesses comuns.

Bastante disseminada no período, a cultura associativa atingia diferentes setores da sociedade, expressando-se nas mais variadas formas de organização - como clubes, sociedades recreativas, esportivas, literárias, musicais; carnavalescas; de teor religioso ou de caridade, entre outras. No mesmo movimento, constituíam-se associações com o objetivo de oferecer, principalmente, atendimentos previdenciários aos seus associados através de uma organização baseada em princípios de ajuda mútua. Eram associações que prestavam assistência financeira em situações de morte, doença, invalidez e, em muitos casos, organizavam espaços de lazer e recreação, de educação e formação, ou mesmo de representação política.

Essas entidades se organizavam a partir dos mais diferentes critérios, a maioria estipulando algum fechamento em torno do grupo social que pretendia atender. Tais fechamentos poderiam estar baseados em sexo, classe, cor, etnia, profissão, religião ou 
qualquer outro. Nessa pesquisa procurou-se analisar as associações organizadas pela classe trabalhadora ${ }^{1 .}$

Mesmo entre esse tipo de associação, encontrou-se diversidade em suas formas de organização, a começar pelo fato de que existiam tanto como voluntárias como compulsórias. Esse segundo tipo de organização ocorria principalmente entre funcionários públicos, como é o caso da União Militar, da Caixa Beneficente da Força Pública e da Sociedade Beneficente do Corpo de Segurança, nas quais o fato de o trabalhador se efetivar enquanto funcionário era suficiente para ser considerado membro, independentemente de seu interesse, sendo a mensalidade descontada de seus vencimentos.

De caráter voluntário, foco dessa pesquisa, localizou-se a existência de trinta e uma associações organizadas por trabalhadores em Florianópolis no período de 1886 a 1932 - o recorte cronológico desta pesquisa se baseou justamente no período de maior existência dessas instituições; , após 1932, as novas organizações assumiram todas um carater sindical. Entre as trinta e uma associações analisadas, seis se organizavam congregando trabalhadores de forma pluriprofissional, sem fechamento em torno da profissão; uma reunia trabalhadores de uma mesma fábrica ${ }^{2}$; duas se organizavam por indústria - reunindo trabalhadores de funções diferentes, mas do mesmo setor industrial -; e vinte e três eram organizadas de acordo com o ofício - sendo que onze delas eram voltadas a trabalhadores do funcionalismo público e doze à trabalhadores envolvidos com o setor privado.

\footnotetext{
${ }^{1}$ Foram localizadas no período de análise duas associações organizadas por princípios étnicos, a Societá di Mutuo Socorso Fratellanza Italiana, fundada em 1891, e a Sociedade Polaca Democrata, de 1901. Elas não foram incluídas entre as associações analisadas pela falta de fontes a respeito de sua organização e grupo social ao qual se dirigiam.

${ }^{2}$ A respeito da União Beneficente da Fábrica de Cartuchos, apenas se pode informar que existiu e teve sua fundação anterior ao ano de 1914, pois, infelizmente, a única notícia a seu respeito que se conseguiu localizar é de uma nota de jornal informando que, em 19 de janeiro desse ano, a sede de tal instituição foi roubada. $O$ Dia, Florianópolis, 19 jan. 1914, n. 7195. (Biblioteca Pública do Estado de Santa Catarina. Doravante BPESC).
} 
Associações de Socorros Mútuos de caráter voluntário organizadas por trabalhadores em Florianópolis:

\begin{tabular}{|c|c|c|c|}
\hline & Associação & $\begin{array}{l}\text { Data de } \\
\text { Fundação }\end{array}$ & Tipo de Fechamento \\
\hline 1 & $\begin{array}{l}\text { Sociedade Beneficente Caixa dos empregados no } \\
\text { Comércio }\end{array}$ & 1886 & Por ofício \\
\hline 2 & $\begin{array}{l}\text { Associação Beneficente e Recreativa dos Empregados } \\
\text { do Comércio }\end{array}$ & 1889 & Por ofício \\
\hline 3 & Liga Operária Beneficente de Santa Catarina & 1891 & Pluriprofissional \\
\hline 4 & Associação Beneficente de Funcionários Públicos & 1897 & $\begin{array}{l}\text { Por oficio - Funcionários } \\
\text { Públicos }\end{array}$ \\
\hline 5 & Associação Beneficente União dos Laboradores & 1899 & Pluriprofissional \\
\hline 6 & $\begin{array}{l}\text { Grêmio Instrutivo e Beneficente dos Empregados no } \\
\text { Comércio }\end{array}$ & 1900 & Por ofício \\
\hline 7 & Club dos Cocheiros & 1900 & Por ofício \\
\hline 8 & União Beneficente dos Artistas & 1902 & Pluriprofissional \\
\hline 9 & Club da Imprensa & $\begin{array}{l}1902 \\
\text { (aprox.) }\end{array}$ & Por ofício \\
\hline 10 & Club dos Bolieiros & $\begin{array}{l}1902 \\
\text { (aprox.) }\end{array}$ & Por ofício \\
\hline 11 & $\begin{array}{l}\text { Caixa Beneficente dos Empregados do Distrito } \\
\text { Telegráfico }\end{array}$ & 1904 & $\begin{array}{l}\text { Por oficio - Funcionários } \\
\text { Públicos }\end{array}$ \\
\hline 12 & $\begin{array}{l}\text { Associação Beneficente dos Guardas das Alfândegas de } \\
\text { Santa Catarina }\end{array}$ & 1907 & $\begin{array}{l}\text { Por oficio - Funcionários } \\
\text { Públicos }\end{array}$ \\
\hline 13 & União Beneficente dos Trabalhadores de Florianópolis & 1910 & De indústria \\
\hline 14 & União Gráfica Beneficente de Santa Catarina & $\begin{array}{ll}1910 \quad \mathrm{e} \\
1917\end{array}$ & Por ofício \\
\hline 15 & União Beneficente da Fábrica de Cartucho & $\begin{array}{l}1914 \\
\text { (aprox.) }\end{array}$ & Por fábrica \\
\hline 16 & $\begin{array}{l}\text { Sociedade Protetora das Famílias dos Funcionários } \\
\text { Públicos }\end{array}$ & 1914 & $\begin{array}{l}\text { Por oficio - Funcionários } \\
\text { Públicos }\end{array}$ \\
\hline 17 & $\begin{array}{l}\text { Associação dos Trabalhadores das Embarcações da } \\
\text { Alfândega }\end{array}$ & 1914 & $\begin{array}{l}\text { Por oficio - Funcionários } \\
\text { Públicos }\end{array}$ \\
\hline
\end{tabular}




\begin{tabular}{|c|c|c|c|}
\hline 18 & União Beneficente dos Padeiros & 1916 & Por ofício \\
\hline 19 & $\begin{array}{l}\text { Congregação dos Náuticos e Pescadores do Estado de } \\
\text { Santa Catarina }\end{array}$ & 1921 & De indústria \\
\hline 20 & $\begin{array}{l}\text { Caixa Beneficente dos Empregados do Ministério da } \\
\text { Fazenda }\end{array}$ & 1921 & $\begin{array}{l}\text { Por oficio - Funcionários } \\
\text { Públicos }\end{array}$ \\
\hline 21 & $\begin{array}{l}\text { Sociedade Beneficente dos Empregados Postais em } \\
\text { Santa Catarina }\end{array}$ & 1921 & $\begin{array}{l}\text { Por oficio - Funcionários } \\
\text { Públicos }\end{array}$ \\
\hline 22 & União Beneficente Operária & 1922 & Pluriprofissional \\
\hline 23 & Caixa Beneficente dos Empregados da Imprensa Oficial & 1923 & $\begin{array}{l}\text { Por ofício - Funcionários } \\
\text { Públicos }\end{array}$ \\
\hline 24 & $\begin{array}{l}\text { Caixa Beneficente dos Funcionários do Tesouro do } \\
\text { Estado }\end{array}$ & 1923 & $\begin{array}{l}\text { Por ofício - Funcionários } \\
\text { Públicos }\end{array}$ \\
\hline 25 & União Beneficente dos Chauffeurs de Santa Catarina & 1925 & Por ofício \\
\hline 26 & Liga do Magistério Catarinense & $\begin{array}{l}1925 \\
\text { (aprox.) }\end{array}$ & Por ofício \\
\hline 27 & União Beneficente Proletária & $\begin{array}{l}1929 \\
\text { (aprox.) }\end{array}$ & Pluriprofissional \\
\hline 28 & União Beneficente dos Garçons de Florianópolis & 1929 & Por ofício \\
\hline 29 & $\begin{array}{l}\text { Associação Beneficente da República e da Imprensa } \\
\text { Oficial }\end{array}$ & 1929 & $\begin{array}{l}\text { Por ofício - Funcionários } \\
\text { Públicos }\end{array}$ \\
\hline 30 & União Beneficente dos Carroceiros & 1931 & Por ofício \\
\hline 31 & Club. dos Funcionários Públicos Civis & 1932 & $\begin{array}{l}\text { Por ofício - Funcionários } \\
\text { Públicos }\end{array}$ \\
\hline
\end{tabular}

\section{AS ASSOCIAÇÕES MUTUALISTAS VOLUNTÁRIAS DE TRABALHADORES EM FLORIANÓPOLIS}

Essas associações possuíam características bastante comuns, em suas formas de se organizar e nos discursos utilizados para ordenar essa organização. Isso se apresenta tanto em relação às suas configurações administrativas - na composição das diretorias, no sistema democrático interno, nas reuniões periódicas dos diretores e na organização financeira e burocrática (através de estatutos, regulamentos internos e livros atas e caixa) - quanto ao que se relacionava às práticas simbólicas - das quais fazem parte os festejos, os símbolos iconográficos, os estandartes e bandeiras, distintivos, diplomas, entre outras representações e formas de construção e consolidação de uma identidade dentre os trabalhadores ${ }^{3}$.

\footnotetext{
${ }^{3}$ HOBSBAWM, Eric. As transformações dos rituais dos operários. In: Mundos do Trabalho. Novos Estudos sobre História Operária. Rio de Janeiro: Paz e Terra, 2000, cap. 05.
} 
O fato de se estar trabalhando com grupos de associações de diferentes categorias demonstra que algumas práticas eram bastante intrínsecas à noção de associação e socorro mútuo, enquanto outras, em suas formas mais singulares, dizem muito a respeito do grupo que dela fazia uso.

Em geral, essas associações se organizavam a partir de um grupo de pessoas com algumas afinidades, desenvolvidas por experiências, interesses e necessidades comuns que, na maioria das vezes, eram estabelecidas através de relações cotidianas - como de amizade, parentesco, de trabalho ou de qualquer outro tipo. Essas relações atuavam de forma marcante, definindo características da organização de cada nova mutual, principalmente nos primeiros anos de uma entidade, quando ainda eram pequenas e em grande parte orientadas por seus fundadores. Dessa maneira, o grupo fundador possuía, na maioria dos casos, uma forte importância na definição dos caminhos e das características que seriam assumidas pela nova associação.

Inicialmente, eram traçadas diretrizes, princípios e metas a serem alcançadas em longo prazo e que se transformariam, antes ou depois da instalação da nova organização, no conjunto de leis a serem seguidas e respeitadas na forma de estatutos, os quais seriam discutidos e aprovados em assembleia geral. Esses estatutos eram modificados com o passar dos anos, adaptando-se às novas necessidades sentidas na atuação prática de cada associação. Hoje, servem como principal fonte de análise a respeito das associações, embora fossem elaborados, em geral, com uma estrutura bem formatada - organizados, na maioria das vezes, com os mesmos elementos de grande parte das associações civis da época; fenômeno bastante comum nas práticas e procedimentos burocráticos que habitualmente se produzem através da utilização de modelos. Além disso, a legislação na qual esse tipo de associação se enquadrava impunha diversas condições a serem seguidas, com requisitos, restrições e limites.

As determinações legislativas tratando a respeito desse tipo de associação tiveram seu inicio em 1860, com a lei n. 1.083, de 22 de agosto e o decreto n. 2.711 , de 19 de dezembro ${ }^{4}$. A lei apenas incorporava essas entidades no conjunto de associações por ela regulamentadas, enquanto o decreto, de forma mais especifica, tratava das entidades de auxílio mútuo ${ }^{5}$. Em suas determinações, previa que toda nova instituição deveria ter seus estatutos aprovados pelo governo antes de iniciar suas atividades, exibindo diversas implicações necessárias, as quais deveriam constar na produção textual de tais estatutos. Os padrões e práticas estipulados por tal decreto, de alguma maneira transformaram-se em modelos, os quais se estenderam para além de sua vigência, pois mesmo com a aprovação da lei n. 3.150, de 04 de novembro de 1882, e do decreto n. 8.821, de 30 de dezembro do mesmo ano - os quais definiam que os estatutos das associações de socorro mútuo não precisavam mais ser submetidos à aprovação

\footnotetext{
${ }^{4}$ SILVA JUNIOR, Adhemar L. da. As sociedades de socorros mútuos: estratégias privadas e públicas. Estudo centrado no Rio Grande do Sul. 1854-1940. 2004. 574f. Tese (Doutorado em História), Curso de Pós-Graduação em História, Pontifícia Universidade Católica do Rio Grande do Sul, Porto Alegre, 2004, p. 297.

${ }^{5}$ Ibidem.
} 
governamental para entrar em funcionamento ${ }^{6}$ - muitas associações continuaram pautando-se pela legislação de 1860. Isso é perceptível fato de os estatutos continuarem a ser redigidos com as mesmas informações exigidas pelo decreto n. 2.711, assim como submetidos para aprovação ao governador do estado ${ }^{7}$. O mesmo tipo de fenômeno é identificado por Adhemar Lourenço da Silva Jr. para o Rio Grande do Sul ${ }^{8}$.

Em 1893, o decreto 173, de 10 de setembro, abriu a possibilidade de que as associações de auxílio mútuo adquirissem personalidade jurídica, com a condição de que publicassem seus estatutos - ou extratos destes - no Diário Oficial (ou nos periódicos que cumprissem o mesmo papel). Tais disposições foram posteriormente consolidadas pelo código civil de $1917^{9}$. Essa medida, de alguma maneira, popularizou os modelos estatutários, disponibilizando-os na imprensa e deixando-os amplamente alcançáveis.

Não se pode, porém, ignorar que, tanto os sujeitos envolvidos no processo de elaboração e aprovação dos estatutos quanto os que posteriormente se associavam, compartilhavam, em alguma medida, das determinações, crenças, intenções e interesses que estavam embutidos na narrativa dos modelos utilizados, apresentando uma compreensão de época do que era e de como deveria ser uma associação deste tipo. Corrobora, no mesmo sentido, o fato de que, para além de uma estrutura protocolar, estes estatutos traziam particularidades que representavam interesses do grupo associado, o que demonstra que não eram simplesmente adotados sem qualquer reflexão. Na atuação prática das associações, a existência de uma compreensão comum a respeito de seus funcionamentos também se expunha, pois nota-se que tais entidades mantinham rotinas muito semelhantes, principalmente em termos administrativos, mas que avançavam também nas práticas sociais.

Os estatutos, em geral, abordavam três conjuntos de temáticas. O primeiro, tratando da organização da associação de forma administrativa e política, apresentava seus fins, composição e função dos membros da diretoria, funcionamento das assembleias, procedimentos eleitorais e demais questões organizativas, incluindo recursos financeiros. $O$ segundo, de questões relativas a presença e participação dos sócios, apresentando os critérios de admissão, as categorias de sócios existentes e seus direitos e deveres (especificando benefícios e cobranças a serem efetuadas pela entidade). Nesse conjunto de assuntos, tratava-se também de questões comportamentais, balizando que tipo de posicionamento se esperava dos sócios, em ambientes de trabalho e nos demais espaços sociais. $E$, em terceiro lugar, havia apontamentos de ordem mais simbólica, como a definição de palavras de ordem, alegorias, escolha das cores a serem assumidas pela associação, datas comemorativas, entre outras representações.

\footnotetext{
${ }^{6}$ Ibidem, p. 300.

7 Ofício enviado pela Associação Beneficente e Recreativa dos Empregados no Comércio para o Governador do Estado. Florianópolis, 30 out. 1899. Cx. 10, fl. 113. Coleção Ofícios de Diversos para o Governador do Estado de Santa Catarina. (Doravante G/S. GNE D - APESC).

${ }^{8}$ SILVA JUNIOR, op cit., p. 300.

${ }^{9}$ DE LUCA, Tânia Regina. O sonho do futuro assegurado. São Paulo: Contexto, 1990, p. 17.
} 


\section{A ADMINISTRAÇÃO POLÍTICA E ECONÔMICA DAS ASSOCIAÇÕES}

Em relação às práticas administrativas das associações, percebem-se características muito comuns no conjunto de entidades analisadas. Em sua maioria, as associações possuíam dois espaços deliberativos: as reuniões de diretoria e as assembleias gerais - sendo estas o fórum soberano de qualquer decisão.

As diretorias eram formadas, exceto pequenas diferenças, por um presidente, um vicepresidente, um primeiro e um segundo secretários, um ou dois tesoureiros e procuradores de números variados. Esses cargos, de ordem política e administrativa, possuíam na maioria dos casos, funções se não iguais, muito parecidas. Além desses cargos, grande parte das associações instituía Comissões, sendo a mais comum delas a de Sindicância, organizada também como Conselho Fiscal, que era responsável por grande parte das relações travadas entre diretoria e associados, uma vez que estava a seu cargo verificar se a idoneidade e a conduta dos candidatos propostos à admissão estavam de acordo com as exigências da entidade, bem como avaliar os pedidos de socorro feitos pelos sócios. Além disso, em grande parte das associações, era também de sua alçada comparecer a enterros representando a instituição. Algumas entidades criavam ainda outros tipos de comissões, como de Finanças ou Hospitalar, efetuando, assim, uma descentralização das funções que geralmente recaíam sobre os membros da Comissão de Sindicância ou Conselho Fiscal ${ }^{10}$.

Em grande parte das associações, havia ainda o cargo de orador oficial, o qual possuía maior diferença de instituição para instituição, tanto no processo de escolha quanto na atribuição de funções. Em algumas entidades, era um cargo definido pelo voto, em outras, era por indicação ou convite, que poderia ser realizado a pessoas não pertencentes ao quadro associativo, oferecendo, em troca, a isenção de pagamentos de taxas, como se costumava fazer em relação à médicos e advogados. Essas diferenças consistiam no fato de que o cargo de orador, ao contrário dos demais, era estritamente político, sem caráter administrativo, com a responsabilidade da imagem pública da associação, uma vez que sua principal função era participar de eventos, pronunciando-se em nome da entidade. Dessa maneira, a nomeação para o cargo pautava-se numa preferência por pessoas eloquentes e com boa capacidade de oração, requisitos que, bem possivelmente, nem sempre se encontravam entre os trabalhadores associados - o que, por certo, acabou levando à criação, em muitas entidades, de mecanismos que restringissem a atuação interna desses membros nas diretorias, sendo compreendido como um cargo de honra. Com isso, tornou-se também um instrumento político de aproximação entre associações e pessoas com influência política e /ou econômica na sociedade local.

\footnotetext{
10 A composição das diretorias e as comissões existentes nas associações florianopolitanas são as mesmas localizadas por Fonseca para as associações do Rio de janeiro. In: FONSECA, Vitor Manoel Marques da. No gozo dos direitos civis: Associativismo no Rio de Janeiro, 1903-1916. Rio de Janeiro/Niterói: Arquivo Nacional/Muiraquitã, 2008, p. 135/136.
} 
A existência de um orador no corpo administrativo da associação pode ser interpretada como um indício do envolvimento social da entidade com a sociedade onde se organizava, o que se tornou possível verificar, uma vez que as instituições que não possuíam esse representante eram, em sua maioria, as mesmas que não apresentavam em seus estatutos a preocupação de fazer de sua sede um espaço de sociabilidade, tratando apenas da prestação de serviços, que eram bastante objetivos e pautados em valores monetários concedidos em casos de necessidade. Entre as associações analisadas, as de funcionários públicos eram as que menos possuíam oradores, presentes apenas nos estatutos da Associação Beneficente dos Guardas das Alfândegas - e mesmo nessa entidade, deixando de existir na reforma estatutária de $1914^{11}$.

As diretorias possuíam a responsabilidade de fazer com que os estatutos fossem seguidos, contornando as dificuldades da atuação prática e, por isso, deveria ser composta por pessoas dotadas de algumas habilidades. Os diretores, no desempenho de seus cargos, de alguma maneira se diferenciavam da base social da instituição, assumindo um papel destacado e tornando-se referência desta. Eram eleitos em assembleia, que ocorria ao término do ano social, na maioria das entidades, para o mandato de um ano.

Havia nos estatutos uma definição do número de reuniões ordinárias e de assembleias gerais a serem realizadas durante o ano social, sendo as extraordinárias efetuadas de acordo com as demandas. Em geral, esse número de encontros era definido com base nas necessidades objetivas, como a eleição da nova diretoria e a apresentação de prestação de contas dos diretores, mas compunha-se também de datas comemorativas, como o aniversário da entidade, o $1^{\circ}$ de Maio e, em alguns casos, a data comemorativa da categoria representada.

Grande parte das associações instituía, para a legitimação das assembleias, que se fizessem convocações pela imprensa local e, com isso, os jornais tornaram-se espaços de aparição cotidiana dessas instituições. A maioria das publicações das associações se dava por pequenas notas, que traziam algum tipo de informativo - como convocações para assembleia; convites para festas, bailes, bazares e quermesses e manifestações artísticas e culturais diversas, de música, dança, teatro ou outro tipo; missas encomendadas; desfiles com caráter reivindicatório ou de homenagens a pessoas públicas, entre outras diversas possibilidades. Além de que, como previsto por lei, se divulgavam comumente trechos dos estatutos ou mesmo seus textos na integra. Publicavam-se também os trechos reformados dos estatutos e, com alguma periodicidade, os resultados de balancetes, assim como a composição das novas diretorias e suas alterações quando ocorridas. Dessa maneira, parte do mundo associativo se expunha em pequenas notas de jornais - pequenas, provavelmente por causa dos custos que uma publicação representava aos cofres sociais.

11 ASSOCIAÇÃO BENEFICENTE DOS GUARDAS DAS ALFÂNDEGAS, Florianópolis. Estatutos, 16 jan. 1910.0 Dia, Florianópolis, 05 mar. 1910, n. 4.474. (BPESC); 02 abr. 1914. Livro 02, fl. 46 a 49 v. (Cartório Faria de Registro Civil, doravante CFRC). 
A constituição dos capitais das associações e a organização de suas finanças se davam de maneiras diversas, mas em geral, respeitavam um padrão comum. Os primeiros estatutos das associações demonstravam entidades recém-organizadas, que precisavam acumular quantias iniciais para dar prosseguimento a suas atividades. Desta maneira, muitas definiam porcentagens que o caixa social deveria alcançar para que começassem a se envolver em operações financeiras mais arriscadas, as quais já vinham, porém, impressas nos estatutos, desde sua formação, como intenções futuras. Quando mais organizadas, geralmente seus caixas se compunham de um fundo "permanente" ou de "reserva" e de um considerado "disponível" (as denominações poderiam variar muito, como de pecúlio e de despesa, A e B, entre outras). O fundo considerado "permanente" era composto pelo patrimônio da sociedade - imóveis, móveis e utensílios, bens de raiz, apólices da dívida pública, entre outros ${ }^{12}$. E o "disponível" ou de "despesa", formado por toda a receita proveniente dos sócios - através de mensalidades, joias, diplomas, multas, entre outros - e dos juros das apólices, verbas de festividades, doações e qualquer outra renda extraordinária que viesse a ocorrer. Esse fundo era utilizado no pagamento dos socorros e nas demais despesas de ordem cotidiana das associações, como o custo de material de escritório, publicidade e a manutenção da estrutura da entidade - nesse sentido, o maior dispêndio se dava no aluguel da sede social, que poderia variar muito, de acordo com o tamanho, qualidade do imóvel e, principalmente, sua localização ${ }^{13}$.

A totalidade das associações aqui analisadas se localizava em bairros centrais da cidade, todos de fácil acesso e grande movimentação urbana, que, no início do século XX, foram os principais alvos das políticas modernizadoras e higienistas, passando por diversos processos de reestruturação e reordenação do espaço ${ }^{14}$. A disposição inicial dos bairros impunha uma grande distância entre as classes, sendo as áreas centrais ocupadas por populações pobres, rodeadas por sítios e chácaras habitadas por uma burguesia. Com as reformas urbanas e o crescimento do

\footnotetext{
${ }^{12}$ Vitor Manoel Fonseca verifica, a partir de uma análise dos estatutos registrados, seguindo a lei n. 173 de 10 de setembro de 1893, que as prioridades de investimento do capital das associações eram para a compra de uma sede própria, vistos sempre como bens estáveis e imunes a flutuações especulativas e na compra de apólices da dívida pública - da União, dos estados ou do Distrito Federal. Segundo o autor, "tudo indica que pareciam ser aplicações rentáveis e seguras, dois aspectos importantes para garantir aos membros a segurança de integrarem uma associação viável e segura financeiramente". In: FONSECA, op cit., p. 133.

${ }^{13}$ A União dos Laboradores pagava, em 1903, a quantia de $6 \$ 000$ mensais por sua sala de sessões ${ }^{13}$, localizada na Rua Almirante Alvim, a qual deveria ser de estrutura bastante simples, pois era apresentada nos balancetes como sala, demonstrando que se tratava de apenas um cômodo. In: Anuário Catarinense, 1904. (BPESC). p. 166; Jornal $O$ Dia. Florianópolis, 14 jan. 1903, n. 608 (BPESC). Cinco anos depois, em 1908, a Caixa dos Empregados no Comércio pagava por aluguel num sobrado à Rua Trajano, n. 05, o valor de $30 \$ 000$ mensais, que, reajustado, passou a $36 \$ 000$ no ano seguinte, se repetindo em 1910. Ibidem, 08 nov. 1907, n. 2.010; Ibidem, 11 maio 1909, n. 4.243; Ibidem, 20 mar. 1914. n. 7347; 25 mar. 1909, n. 4.209; Ibidem, 09 jan. 1910, n. 4.433. A Liga Operária em período próximo, no ano de 1905, recebeu a quantia de $516 \$ 000$ anual pelo aluguel de casa no centro da cidade, o que equivaleria a um aluguel de $43 \$ 000$ mensais. Apenas para comparação, um trabalhador catarinense recebia, em média, $6 \$ 000$ diários. Ibidem, 21 fev. 1906, n. 1.517.

${ }^{14} \mathrm{Em}$ seu estudo a respeito do associativismo no Rio de Janeiro, Vitor Manoel Fonseca detectou que $93,04 \%$ das associações existentes na cidade se localizavam em distritos urbanos, predominando na área central. In: FONSECA, op cit., p. 162.
}

Revista Mundos do Trabalho, vol. 4, n. 7, janeiro-junho de 2012, p. 57-84. 
comércio, essas regiões valorizaram-se. Aos poucos, os pobres foram levados a deixar o centro, afastando-se em direção aos morros, que já em 1876, apresentavam alguma ocupação, ainda discreta e de poucas casas isoladas ${ }^{15}$. Nesses bairros centrais, as associações optavam por ruas marginais, de pouca valorização e em boa medida com condições ainda bastante precárias. Apenas como exemplo, a Rua Pedro Soares - endereço de um dos primeiros imóveis da Liga Operária, onde posteriormente foi construída a sede da União Operária - era uma subida de terra com acentuado declive, sem calçamento, esburacada e de difícil acesso, de uso apenas para pedestres. Localizada num bairro marginal da cidade, a Tronqueira, não possuía, ainda, nos anos de 1920, iluminação pública e se constituía numa das "vielas mais sórdidas da cidade" ${ }^{16}$.

Pelo aluguel representar um alto custo, as associações recém formadas - e, portanto, sem base financeira sólida - iniciavam suas atividades reunindo-se em espaços emprestados e de uso habitual dos envolvidos, comumente, a casa de algum dos membros da nova entidade, mas também bares, salões ou mesmo a sede de alguma instituição similar frequentada por alguns dos sócios. Esses espaços eram utilizados sempre com um caráter provisório, pois a maioria das entidades apresentava, desde a sua fundação, o desejo de possuir um espaço que lhes fosse próprio, mudando, assim que tivesse condições, para estruturas alugadas e, em alguns casos, adquirindo sede própria.

Por conta da característica transitória do aluguel - por envolver diferentes situações, como a oferta de preços, as condições do imóvel em relação às demandas da associação, o aumento ou queda das condições financeiras da entidade, a mudança nos interesses do proprietário, entre outros - a grande maioria das sedes era bastante instável, percebendo-se inúmeras mudanças pelas quais as associações passavam em sua história. Por isso, o desejo de conquistar uma sede própria se fazia presente na maioria dos estatutos das entidades, aparecendo em grande parte dos casos como uma prioridade em relação à finanças da instituição. Uma sede própria, para além de significar o fim do incômodo das inúmeras mudanças e do constante dispêndio com aluguel, se explica também pelo fato de que um espaço físico possibilitava uma organização de maior qualidade dos trabalhos desempenhados pela entidade - desde reuniões e assembleias a qualquer tipo de evento cultural ou recepção. Era também um avanço para a efetivação de projetos, já que grande parte das entidades pretendia exercer atividades que demandavam espaços apropriados, como a organização de escolas, teatros, filarmônicas ou mesmo simples bibliotecas. Além disso, a existência de uma estrutura física própria corroborava sua seriedade. A Liga Operária, a partir do momento em que conquistou seu primeiro imóvel, passou a incluir em todas as chamadas na imprensa local,

\footnotetext{
${ }^{15}$ ARAÚJO, Hermetes Reis de. A Invenção do Litoral. Reformas urbanas e reajustamento social em Florianópolis na Primeira República. 1989. 216 f. Dissertação (Mestrado em História), Curso de Pós Graduação em História, Pontífice Universidade Católica de São Paulo, São Paulo, 1989, p. 36.

${ }^{16}$ VEIGA, Eliane Veras da. apud: COLLAÇO, Vera. O Teatro da União Operaria: um Palco em Sintonia com a Modernização. 2003, 335 f. Tese (Doutorado em História Cultural), Curso de Pós-Graduação em História, Universidade Federal de Santa Catarina, Florianópolis, 2003, p. 14/15.
} 
em letras garrafais, a informação "Sede Própria", demonstrando o orgulho e a diferenciação que esse fator representava.

Na prática, servia ainda como um espaço de sociabilidade e lugar de constituição e manutenção de identidades, propiciadas pela organização interna que as sedes sociais assumiam, privilegiando espaços amplos de convívio social dos mais diversos - de assembleias e reuniões a bailes e sessões de jogos $^{17}$. A descrição da organização interna da sede da União Operária é bastante ilustrativa nesse sentido: "O prédio [...] possui dois espaçosos salões [...], onde estão instaladas a secretaria, tesouraria, etc. $\mathrm{O}$ salão superior foi destinado às atividades teatrais, sessões da diretoria e assembleias gerais e no salão inferior ficava a biblioteca e a parte administrativa" ${ }^{18}$.

A partir das associações das quais foi possível localizar maior conjunto de informações, percebeu-se que alcançar capital suficiente para adquirir uma sede própria poderia levar muito tempo - no caso dessas entidades, uma média de dez anos depois de sua fundação. A compra de imóveis se configurava nos estatutos de muitas entidades também como uma forma de investimento e ampliação de capitais, que rendiam aluguéis e própria valorização do imóvel. Outra forma de investimento dos capitais utilizada pelas associações, ainda relacionada a imóveis (compra, construção ou reforma), era a realização de empréstimos aos sócios, através da assinatura de hipotecas, que seriam cobradas mensalmente com juros ${ }^{19}$. Essa maneira de investir o capital possuía ainda o caráter de beneficio, pois era oferecido de acordo com as condições do associado e de forma muito mais facilitada do que em agências de crédito. Embora não apresentassem essa possibilidade em seus estatutos, entidades como a Liga Operária e a União dos Laboradores contavam com o pagamento dessas hipotecas em suas receitas mensais. Outras associações previam estatutariamente o empréstimo a juros para os seus associados, atividade bastante presente principalmente nas associações de funcionários públicos, as quais caracterizavam tal iniciativa como parte de seus benefícios.

Mas a forma mais rentável de se investir os capitais, utilizada principalmente pelas entidades que alcançavam um fundo social considerável, se dava pela compra de apólices da dívida pública, as quais valiam pelos juros semestrais que rendiam. Essas apólices poderiam ser de qualquer instância do poder público - municipal, estadual, ou federal - e eram computadas anualmente na prestação de contas das associações como parte do fundo social. Essas apólices da divida pública eram utilizadas pelo Estado como forma de subsidio. A Liga Operária, ao que tudo indica, era a única que, aparentemente, era subvencionada por benefícios provenientes de loterias.

\footnotetext{
${ }^{17}$ Adhemar Silva Jr. expressa várias possibilidades sobre a importância de se ter uma sede para a associação. Cf. SILVA JUNIOR, op cit., p. 217 a 220.

${ }^{18}$ COLLAÇO, op cit., p. 91.

${ }^{19}$ Paula Nomellini percebe o mesmo fenômeno em sua pesquisa. Cf. NOMELINI, Paula Christina Bin. Associações operárias mutualistas e recreativas em Campinas (1906-1930). 230 fl. Dissertação (Mestrado em História), Curso de Pós-Graduação em História. Universidade Estadual de Campinas, Campinas, 2007, p. 64-65.
} 
Não raras vezes, essas entidades, na ampliação de seus capitais, recorriam também à comunidade, organizando eventos beneficentes. As quermesses e os bazares eram as formas mais comuns de organização de eventos visando lucro, embora existissem outras formas de arrecadação. Na Liga do Magistério, por exemplo, era adotado o livro-ouro (no qual o doador registrava seu nome e a quantia doada, tornando a doação, de alguma maneira, pública). Havia também a possibilidade de se organizar eventos como bailes, festas, e mesmo atividades esportivas, cobrando ingressos. Em 1927, a União Beneficente dos Chauffeurs, por exemplo, organizou uma atividade festiva para arrecadação de fundos, em que a principal atração era um jogo de futebol com o Trabalhista Futebol Club $^{20}$. Esses tipos de medidas de arrecadação eram mais pontuais, com destinação, na maioria dos casos, pré-estabelecida.

A maior forma de arrecadação das associações se baseava na cobrança dos sócios, de diferentes taxas previstas estatutariamente. Logo que se filiava, o sócio precisava despender uma quantia significativa para o pagamento de diferentes obrigações, efetuando, posteriormente, apenas o pagamento de suas mensalidades. Em todas as entidades, a primeira cobrança realizada era a joia de admissão, que funcionava como uma espécie de matrícula. Seus valores variavam bastante de instituição para instituição e mesmo dentro de algumas associações, que diferenciavam o valor de acordo com a idade do ingressante. A medida era utilizada para se compensar o fato de que as pessoas de mais idade, provavelmente, precisariam de mais atendimentos, significando maiores custos à instituição. Em algumas entidades, além da joia de entrada, o novo associado deveria pagar pelo diploma de sócio; em outras ainda, o valor de um distintivo - que poderia ser um botão, um broche ou qualquer outro tipo de adereço a ser exibido. Serviam como elemento diferenciador e para destacar publicamente que tal indivíduo fazia parte do corpo social da entidade. Depois disso, o associado deveria manter-se pagando suas mensalidades, as quais the permitiriam usufruir dos direitos de sócio - principalmente, o de receber socorros, de votar e ser votado. Os valores das mensalidades não variavam muito de associação para associação.

Havia ainda, em relação aos sócios, os ganhos provenientes de remissões - que ocorriam quando o associado quitava grande quantidade de pagamentos de suas mensalidades e demais taxas de uma só vez, desresponsabilizando-se de pagá-las mensalmente. E o pagamento realizado na compra de títulos de sócios beneméritos. Estes ganhos decorrentes dos sócios representavam quantias mais do que significativas na receita das associações. Na União dos Laboradores, por exemplo, $87 \%$ da receita adquirida de agosto a dezembro de 1902 veio dos pagamentos de sócios. Mais interessante é o exemplo da Sociedade Caixa Beneficente dos Empregados no Comércio, que no decorrer de vários anos, demonstra um padrão, no qual somente a mensalidade representava a maior parte do rendimento mensal, atingindo um valor

\footnotetext{
${ }^{20}$ UNIÃO BENEFICENTE DOS CHAUFFEURS DE SANTA CATARINA. Florianópolis. ata n. 24, assembleia geral de 01 fev. 1927. Livro de atas das sessões de 1925 a 1936, fl. 24. (Arquivo da Associação); Ibidem, ata n. 25, assembleia geral de 15 dez. 1927, fl. 25.
} 
aproximado de $70 \%{ }^{21}$. Mesmo na Liga Operária, que era a associação que mais possuía receitas extras, os valores provenientes dos sócios eram os mais representativos. No ano de 1905, estes chegaram a um total de $50 \%$ da receita da associação, estando os outros $50 \%$ distribuídos em outras fontes de arrecadação (4\% no pagamento de aluguéis de casas de sua posse; $5 \%$ de juros de apólices; $15 \%$ provenientes de hipotecas, entre juros e capitais líquidos; $18 \%$ vindo das loterias pagas pela Delegacia Fiscal; e 7,8\% de uma apólice sorteada).

Porém, da mesma maneira que os sócios eram os que geravam a maior parte da receita das associações, eram também os que causavam seus maiores dispêndios. Na União dos Laboradores, por exemplo, no mesmo ano de 1902 , em que $87 \%$ de sua receita se formou a partir de cobranças realizadas no quadro associativo, $85 \%$ de suas despesas foram realizadas em atendimentos de socorros dos mais diversos tipos. Da mesma forma, na Liga Operária, em 1905, $50 \%$ da receita da entidade procedeu do pagamento de associados e $31 \%$ de suas saídas foram destinadas a socorros. No ano de 1929, na mesma instituição, este tipo de serviço chegou a assumir $62 \%$ das despesas. Analisando os balancetes da Sociedade Beneficente Caixa dos Empregados no Comércio, percebe-se que, no decorrer dos anos, os gastos alcançados pelos socorros chegavam a $90 \%$ dos custos da associação. Este fenômeno faz muito sentido, uma vez que essas instituições eram criadas com o objetivo de atender pecuniariamente seus associados, oferecendo socorros em casos de necessidades.

\section{A PARTICIPAÇÃO DOS SÓCIOS - DIREITOS E DEVERES}

Analisar a configuração do corpo associativo das entidades certamente é de grande relevância para compreendê-las, uma vez que tanto o surgimento quanto a manutenção de uma associação só se explica pelo fato de existirem pessoas a ela associadas, fazendo uso de seus serviços e possibilitando sua existência material. Esses sujeitos - imbuídos de interesses e necessidades - davam à suas associações características intimamente relacionadas a seus anseios e compreensões de mundo.

A composição dos membros, em boa parte, era orientada por definições previamente elaboradas e aprovadas nos estatutos, que refletiam - de diferentes formas - interesses e valores oriundos daqueles que os haviam aprovado enquanto leis a serem seguidas. Esse tipo de orientação delineava o grupo social de interesse da associação, atraindo ou repelindo novos membros. A primeira maneira estatutária de se restringir - e assim, de alguma forma definir - 0 grupo social que pertenceria à associação, explicitava-se nos artigos que expunham quem poderia se associar, através de requisitos como idade mínima e máxima e a necessidade de se possuir boas condições de saúde. Grande parte das instituições expunha também requisitos

\footnotetext{
${ }^{21}$ No ano de 1902, correspondeu a 76\%, no de 1903 e de 1904, a 71\%, e no de 1905, a 68\%. O Dia, Florianópolis, 04 abr. 1902, n. 375. (BPESC); ibidem, 02 ago.1903, n. 614; ibidem, 08 dez. 1904, n. 1114; ibidem, 28 mar. 1905, n. 1251; ibidem, 29 mar. 1906, n. 1546.
} 
morais em relação ao futuro associado Esse tipo de preocupação estava distribuída em toda a narrativa textual dos estatutos das mais diferentes associações, mas enquanto critério de admissão de novos sócios, se fazia presente principalmente nas associações de trabalhadores manuais de categorias pouco valorizadas socialmente na época.

As associações de funcionários públicos, ao contrário, não estipulavam requisitos para filiação, situação que pode demonstrar tanto que essas entidades não se viam como responsáveis pelos trabalhadores a elas associados como que estes não carregavam um estigma social do qual sentissem necessidade de se livrar, pois possuíam uma colocação social bastante diferenciada.

O quanto tais critérios eram definidores, pode ser observado no Livro de Matrículas da Liga Operária, que, embora seja uma fonte falha, por expressar quantias menores de nomes doque as expressas em atas, funciona como uma amostragem do quadro social da entidade de 1891 a 1930. Em suas anotações, observa-se que a faixa de idade mais comum entre os sócios era de 15 a 30 anos (66\% do total de membros), e que o quadro social era composto, em sua maioria, por pessoas do sexo masculino ( $70 \%$ do total de sócios). Ambas as situações podem ser compreendidas pelas imposições estatutárias direcionadas aos filiados: a primeira, pela exigência em relação à idade mínima e máxima para se associar (de 15 a 60 anos), e pela necessidade de se apresentar boa saúde e estar empregado, o que, de alguma maneira, limitava a entrada de pessoas com mais de 30 anos, pois, além de mais propícias a doenças, já eram consideradas velhas no mercado de trabalho ${ }^{22}$. Em relação às mulheres, havia um tratamento diferenciado, impedindo-as, por exemplo, de votarem e serem votadas - o que demonstra que realmente não eram o foco de tal instituição.

Em relação à profissão dos sócios, outras questões tornam-se perceptíveis, embora se configurasse um quadro bastante eclético nesse sentido. Entre os 480 nomes verificados, 51 profissões diferentes foram declaradas, sendo que nenhuma delas representava um conjunto muito expressivo de pessoas. A profissão que mais se repetia era a de doméstica, que poderia representar diversas atividades desempenhadas pelas mulheres no âmbito do lar, ou como extensão deste ${ }^{23}$. Entre as profissões presentes no livro de filiados da Liga Operária, eram pouquíssimos os trabalhadores que possuíam profissões que se enquadravam em entidades de ofício e indústria, sendo que o maior número era de marítimos e estivadores (que somavam 47 pessoas). As demais profissões apresentavam números bastante irrisórios (1 carroceiro, 5 chauffeurs, 5 motoristas, 11 padeiros, 9 professoras e 24 tipógrafos), sendo a maioria do grupo de associados formada por alfaiates, barbeiros, carpinteiros, marceneiros, sapateiros, pintores,

\footnotetext{
${ }^{22}$ Considerando que a população mais velha da cidade, em números significativos, tinha no máximo 50 anos. In: Recenseamento do Brasil, realizado em 01 de setembro de 1920, Rio de Janeiro: Tipografia da Estatística, 1930. vol. 4, tomo I, pt. 2. p. XL/XLI.

${ }^{23}$ Incluindo a prática de profissões como as de lavadeira, cozinheira, arrumadeira, entre outras. In: PEDRO, Joana Maria. Mulheres honestas e mulheres faladas: uma questão de classe. (Doutorado em História), Faculdade de Filosofia, Letras e Ciências Humanas. Universidade de São Paulo, 1992, p. 231.
} 
as citadas domésticas, entre outras ${ }^{24}$. Partindo desses dados, é possível perceber que as associações abertas, sem fechamento voltado para o ofício, realmente atraíam trabalhadores artesãos, informação que se confirma nos estatutos da União Operária, a qual apresentava que o associado deveria "respeitar a disciplina, amar o trabalho e desvelar-se pelo aperfeiçoamento dos seus produtos nas oficinas" ${ }^{25}$ [grifo nosso]. Esses trabalhadores, em grande parte, pertenciam a categorias que tinham como característica o trabalho individual, informação que permite aferir que estes buscavam se organizar unindo-se com outros grupos de trabalhadores, uma vez que não possuíam uma tradição organizativa nem um contato tão presente para que se unissem por ofício ${ }^{26}$.

No caso das associações organizadas por oficio e indústria, seu maior diferencial definiase justamente no estabelecimento de critérios de admissão, pois enquanto as de cunho pluriprofissional - por serem entidades abertas em relação ao ofício de seus associados - o faziam através dos critérios gerais acima expostos, as de ofício definiam seu público principalmente por fechamentos voltados à profissão de seus membros, estipulando de forma bem definida um grupo social preferencial a ser atendido. Este critério escolhido como princípio de organização pelas associações de ofício tinha um papel de extrema importância no desenvolvimento de todas as demais resoluções da entidade e, consequentemente, em sua atuação prática, pois a partir dessa resolução, assumia-se uma atuação orientada aos interesses de uma categoria ou grupo profissional.

Nas associações de funcionários públicos, esse tipo de especificação se voltava mais à própria condição dos trabalhadores enquanto empregados do Estado - respondendo às pequenas diferenças e interesses mais específicos que esse tipo de relação empregatícia desencadeava - do que propriamente em relação às funções desempenhadas pelas diferentes ocupações e obrigações de cada setor interno da administração estatal, de forma que acabavam assumindo uma atuação voltada a interesses que correspondiam a todo conjunto de funcionários públicos, sem atuar diretamente em especificidades de cada categoria. Assumia, assim, uma atuação quase pluriprofissional em relação aos trabalhadores inseridos em setores do funcionalismo, como é o caso da Sociedade Protetora dos Funcionários Públicos Civis, da qual poderiam fazer parte "todos os empregados públicos civis federais, estaduais e municipais, de ambos os sexos, guardas e despachantes gerais das Alfândegas e Mesas de Rendas federais e estaduais, bem como os empregados aposentados" ${ }^{27}$; limitavam nessa determinação, porém, de maneira expressiva, os trabalhadores que não pertencessem ao funcionalismo.

\footnotetext{
${ }^{24}$ LIVRO de Matrículas dos sócios da Liga Operária Beneficente de Florianópolis. 1891-1960. (Acervo da Associação).

${ }^{25}$ UNIÃO BENEFICENTE OPERÁRIA. Estatutos. Florianópolis: ed. Escola de Aprendizes Artífices. Florianópolis, 1922. Cap. XIII, art. 55, p. 17 (cópia cedida por Vera Regina Martins Collaço).

${ }^{26}$ BATALHA, Claudio. O movimento operário na Primeira República. Rio de Janeiro: Jorge Zahar, 2000, p. 16.

27 SOCIEDADE PROTETORA DOS FUNCIONÁRIOS PÚBLICOS CIVIS, Florianópolis. Estatutos, 25 out. 1914 . O Dia, Florianópolis, 03 dez. 1915, n. 8325. Cap. II, art. 05. (BPESC).
} 
Os estatutos das associações organizadas por ofício se apresentavam, à primeira vista, rígidos em relação à entrada de pessoas que não pertencessem às áreas e profissões escolhidas, principalmente enquanto sócios contribuintes - que compunham a maioria do corpo social das entidades. Todavia, percebe-se que, em muitos casos, essa rigidez dos princípios era driblada ao longo das demais determinações estatutárias, a fim de possibilitar maior circulação na constituição do quadro social. Existia, por exemplo, diferentes categorias de sócios para além do contribuinte, em relação aos quais as associações flexibilizavam os requisitos de admissão. Entre eles, estavam os denominados sócios beneméritos, benfeitores, protetores e honorários; em alguns poucos casos, correspondentes e ausentes ${ }^{28}$. Na maioria das vezes, a definição desses títulos - principalmente os de benemérito, protetor e honorário - correspondia a interesses de ordem política e econômica das associações, pois, em grande parte, as pessoas homenageadas estavam em evidência no cenário político e social local e possuíam boas relações e influência, sendo por isso "merecedoras" desses títulos e/ou por desempenharem doações significativas às entidades - tanto de valores monetários quanto simbólicos.

Provavelmente, a dificuldade que a manutenção de um corpo social fechado significava impulsionou algumas instituições a realizar pequenas aberturas nos critérios de admissão por elas mesmas instituídos, permitindo que trabalhadores de outras áreas e profissões fossem admitidos como sócios contribuintes. Em Florianópolis, três entidades assumiram essa postura: a União Beneficente dos Padeiros, a União Beneficente dos Chauffeurs de Santa Catarina e a União Beneficente dos Trabalhadores de Florianópolis. Nessas associações, tudo indica que o processo de abertura tenha sido realmente utilizado como estratégia de crescimento, pois em todos os casos, se deu cerceada por algum tipo de restrição, principalmente de ordem política, demonstrando que a instituição continuava, mesmo que admitindo novos conjuntos de trabalhadores, com o interesse bastante focado no grupo social inicial ao qual se direcionara. No caso da União dos Chauffeurs, as restrições políticas por vezes trouxeram dificuldades na organização do corpo diretivo, para as quais se utilizaram os estatutos como solução, impondo restrições para proteger politicamente os interesses da categoria. No caso da União dos Trabalhadores, a abertura para outras categorias se associarem foi modificando a forma e os objetivos de atuação da entidade, direcionando-a cada vez mais para uma atividade pluriprofissional. Ainda assim, procurou manter características de organização de indústria, voltada prioritariamente aos trabalhadores do mar - estivadores e marítimos.

Tal observação leva a uma compreensão das influências que os critérios de admissão ocasionavam na organização e na prática das associações, uma vez que, ao recortar o público definiam importantes princípios pelos quais procurariam trabalhar. Questão que se refletia nos estatutos das mais diferentes maneiras, sendo a mais significativa delas a definição dos

\footnotetext{
${ }^{28}$ A definição pelos estatutos de cada um dos títulos encontradas nas associações de Florianópolis são as mesmas apresentadas por Vitor Manoel Marques da Fonseca, que analisou os estatutos das associações do Rio de Janeiro. FONSECA, op cit., p. 130.
} 
socorros, pois eram planejados e deveriam estar de acordo com o grupo social que se pretendia atingir. Sendo assim, através da análise dos benefícios oferecidos pelas associações, naquilo que elas priorizavam ou mesmo no que não se propunham a prestar, muito se pode saber a respeito dos trabalhadores que a elas se associavam, verificando interesses e demandas.

A prestação de socorros era um fator determinante no processo de organização das entidades beneficentes, uma vez que surgiram com o objetivo de suprir as principais carências que atingiam os trabalhadores, em uma época em que não havia legislações sociais e trabalhistas que lhes trouxessem segurança; os trabalhadores que se viam envolvidos em casos de doenças, mortes, invalidez ou desemprego ficavam completamente desamparados. Além disso, os salários não eram garantia de sobrevivência, pois eram baixos e não supriam as necessidades de uma família inteira: "quem dependia do seu próprio trabalho para sobreviver [...] estava sujeito a pobreza na circunstancia inevitável da doença e da morte" ${ }^{29}$.

Os socorros buscavam contemplar as necessidades mais elementares - ligadas à saúde, lazer e educação - cumprindo um papel previdenciário. Poderiam também, dependendo da associação, atingir interesses mais específicos e até mais combativos, atuando diretamente no mercado de trabalho.

Grande parte das associações priorizava os atendimentos voltados a morte e enfermidades, fenômeno que certamente se relacionava com a grande procura dos trabalhadores brasileiros desassistidos por esses benefícios. No caso dos atendimentos relacionados à saúde, é extremamente compreensível que tenham se tornado quase obrigatórios, pois a saúde pública foi uma questão crítica durante toda a Primeira República. Em Santa Catarina do começo do século XX, as doenças endêmicas alastravam-se, e a expectativa de vida era de 50 anos $^{30}$. O primeiro Hospital do estado, o Hospital Real (hoje Militar), foi fundado em Florianópolis em 1769; apenas vinte anos depois, foi fundado o Imperial Hospital de Caridade, também na capital catarinense. Em 1924, para doenças contagiosas, inaugurou-se o Hospital Regional ${ }^{31}$, porém, havia ainda poucos leitos para a grande demanda de todo o estado de Santa Catarina. O atendimento médico domiciliar era bastante comum e necessário. As curandeiras e benzedeiras também possuíam amplo espaço quando se tratava de saúde ${ }^{32}$. Além das precárias condições do atendimento médico oferecido pelo Estado, a insegurança no

\footnotetext{
${ }^{29}$ MARTINS, José de Souza. Subúrbio. Vida cotidiana e história no subúrbio da cidade de São Paulo: São Caetano, do fim do império ao fim da República velha. São Paulo. Hucitec/Prefeitura da São Caetano do Sul, 1992, p. 183.

${ }^{30}$ ZEFERINO, Augusto César. A expansão da rede urbana. In: PEREIRA, Nereu do Vale. A Ilha de Santa Catarina: espaço, tempo e gente. 2 v. Florianópolis: Instituto Histórico e Geográfico de Santa Catarina, 2002, p.109.

${ }^{31}$ Ibidem, p. 177.

${ }^{32}$ Entre elas, ficou muito conhecida a filha de escravos Rita Maria, que, de tanto ser procurada, denominou o local onde morava - o bairro Rita Maria, anteriormente chamado Praia da Feira. Atualmente, o Terminal Rodoviário de Florianópolis, assim como um Espaço Cultural, levam o seu nome. Segundo Osvaldo Rodrigues Cabral, Rita Maria teria vivido nesse local entre os séculos XVIII e XIX, pois nos mapas datados de 1794, já constavam os locais com o seu nome. Disponível em:

<http://www.deter.sc.gov.br/www/index.php?modulo=conteudo\&int_seq_secao=25\&int_seq_subsecao=80\&int_s eq_conteudo=24>. Acesso em 13 set. 2008.
}

Revista Mundos do Trabalho, vol. 4, n. 7, janeiro-junho de 2012, p. 57-84. 
trabalho transformava as faltas por doença em um grande problema, pois só se recebia por dia de trabalho e corria-se o risco de perder o emprego durante a ausência, além da necessidade de arcar com os custos de uma enfermidade ${ }^{33}$.

Os tipos de atendimento e formas de prestação dos socorros para enfermidades poderiam variar bastante nas associações. A forma mais comum era o oferecimento de diárias por dia de doença, que respeitava um procedimento de verificação do caso para que se pagasse o pecúlio. Depois das diárias, o socorro para enfermidades mais prestado era o auxílio médico, que consistia no financiamento de uma consulta residencial ou em consultório. Muitas associações possuíam interesse em manter um médico para realizar tais atendimentos, porém, poucos estatutos regularizavam esse vínculo, em geral estabelecido através da admissão do profissional no corpo social sem cobrança de taxas. Havia outros tipos de socorro para casos de enfermidade, como o auxílio farmácia, estipulando um valor máximo que poderia ser despendido por pessoa na compra de remédios; um auxílio transporte, para os que precisassem sair da cidade em busca de tratamento; auxílio hospitalar, destinado aos que necessitassem de internação; e, em raros casos, o auxílio cirúrgico, por conta do alto custo que esse atendimento representava.

O único tipo de socorro prestado por todas as associações analisadas eram os voltados à morte. Isso, principalmente porque, para além da questão econômica, o funeral possuía um significado moral, pois ter um "enterro decente" dava ao trabalhador uma noção de dignidade e diferenciação dos que eram muito pobres e necessitavam de enterros públicos.

Em grande parte dos estatutos as prescrições a cerca dos funerais se faziam acompanhar da idéia de decência, como se estivessem a marcar a distância em relação ao tratamento dado ao indigente. [...] De fato, o "conforto material" requerido nesses casos era bastante dispendioso [...]. O Estado fornecia gratuitamente os serviços funerários para os pobres; contudo, essa alternativa deparava-se com um forte componente cultural: a preocupação de ser enterrado condignamente e se possível às expensas próprias ${ }^{34}$.

Esse tipo de socorro proporciona, portanto, a possibilidade de uma anállise comparativa entre as formas de atendimento propostas e seus significados. As entidades de ofício, tanto do setor público quanto do privado, tratavam esses benefícios relacionados à morte de maneira bastante administrativa e objetiva, buscando apenas responder quais seriam os valores dispensados e as formas de pagamento. Diferenciavam-se pelo fato de que as associações de funcionários públicos ofereciam, na maioria dos casos, quantias maiores no pagamento desse tipo de socorro - o que é bastante interessante, uma vez que esses trabalhadores estavam

\footnotetext{
${ }^{33}$ BATALHA, op cit., $\mathrm{p} 11$.

${ }^{34}$ DE LUCA, op cit., p. 29.
} 
protegidos por lei em tais situações, ficando o Estado responsável por financiar parte do funeral de seus empregados com quantias estabelecidas ${ }^{35}$.

A União Beneficente de Chauffeurs e a União dos Trabalhadores de Florianópolis organizadas por ofício e por indústria, anteriormente mencionadas por assumirem um grupo social mais heterogêneo de trabalhadores - se assemelhavam, na prestação dos socorro, às associações pluriprofissionais, por fazerem uso de práticas rituais mais elaboradas. Para essas entidades, sua responsabilidade em relação à morte ia além de uma prestação de serviço monetário, ganhando diversos outros significados. Além de servir para responder às expectativas pessoais do sócio e seus familiares, a construção de um ritual funerário bonito era interessante também por ser um momento no qual se ganhava visibilidade, divulgando o nome da instituição e seus serviços. Em muitos casos, era comum convidar pessoas consideradas ilustres (como os sócios beneméritos, a imprensa e até mesmo representantes do governo), que poderiam render notas em jornais sobre os presentes, discursos proferidos e até mesmo o número de coroas de flores recebidas.

Esse momento de comoção também atuava fortemente para fortalecer relações identitárias entre os sócios. Comumente, as práticas desenvolvidas no evento funerário consistiam em depositar sobre o caixão do sócio a bandeira da entidade e proferir discursos de engrandecimento, relacionando-o com a história da instituição. Da mesma forma, boa parte das associações mantinha entre suas determinações estatutárias a obrigatoriedade da participação de sócios (ou de pelo menos uma comissão) nos funerais, exacerbando, assim, um sentimento de grupo. Na União dos Trabalhadores de Florianópolis, por exemplo, chegou-se a planejar a construção de um jazigo destinado a todos os associados falecidos que não tivessem herdeiros, deixando clara a intenção de construir uma relação "familiar" e de forte identificação entre associação e seus membros ${ }^{36}$.

Da mesma maneira, as associações tinham por costume mandar rezar missas em nome de seus sócios falecidos. Eram eventos que possuíam o mesmo repertório que os funerais, contando com pessoas influentes socialmente e publicações na imprensa local. Nessas missas, as condolências eram dirigidas aos diretores, principalmente ao presidente da associação, mais uma vez demonstrando que a morte era compreendida como uma perda social de uma grande família.

O fato de as associações com princípios admissionais abertos assumirem esse tipo de atuação mais ritualizada em relação a seus benefícios fúnebres parece ter total conexão com as

\footnotetext{
${ }^{35}$ SANTA CATARINA, Lei n. 788, de 31 de agosto de 1908. Institui a favor dos funcionários o quantitativo de $150 \$ 000$ para funerais. Lex: Coleção de Leis. Joinville: Tipografia SOEMM; SANTA CATARINA, Lei n. 1.504, de 16 de outubro de 1925. Elevando para trezentos mil réis o quantitativo estabelecido para os funerais dos funcionários públicos do Estado. Lex: Coleção de Leis, Decretos e Resoluções (Centro de Memória da Assembléia Legislativa do Estado de Santa Catarina. Doravante CMALESC).

${ }^{36}$ UNIÃO BENEFICENTE DOS TRABALHADORES DE FLORIANÓPOLIS, Florianópolis. Estatutos, 06 set. 1913. Livro 02, fl. 34 v. Cap.IX, art. 70 (CFRC).
} 
demandas do público que lhes pertencia e que pretendiam atrair, o que demonstra a existência de certo perfil também nas entidades que possuíam um corpo social formado por diversas profissões. Aglutinava-se trabalhadores por identidade, não baseada na profissão, mas em algumas das demais especificidades de sua organização - fossem os valores geralmente acessíveis das mensalidades, os socorros bastante amplos, o perfil do corpo de associados, as limitações impostas para a filiação, o ambiente interno, com espaços de sociabilidade, as formas rituais que praticavam, as campanhas em que se envolviam, sua localização, entre tantas outras possibilidades.

Depois dos atendimentos voltados a morte e enfermidades, os mais prestados eram os relacionados à invalidez. Nesse sentido, a atuação da maioria das entidades se limitava à isenção das taxas internas da associação. O direito a pensões mensais era prestado por poucas entidades, por conta da sua regularidade de pagamento e, portanto, alto custo de manutenção. Assim, as associações que o propunham, em geral, o faziam com ofertas simbólicas, mais por uma questão de princípios, por reconhecerem as dificuldades encontradas pelos trabalhadores idosos e acidentados, sem condições de prover seu próprio sustento ${ }^{37}$. Simbólicos também eram os socorros ofertados em casos de desemprego, com a diferença de que apenas quatro associações se dispunham a prestá-lo, provavelmente, pelo fato de ser um socorro por tempo indeterminado e de difícil manutenção ${ }^{38}$.

Outro conjunto de socorros bastante presente no leque de prestações das entidades era voltado à instrução, que se apresentava tanto através da construção de bibliotecas, muito comuns neste meio associativo, quanto na constituição de escolas. Na maioria dos casos, as bibliotecas se formavam através de doações, sem ônus para a associação. Poucas entidades destinavam verba própria para manutenção e compra de livros. Grande parte das associações que possuíam bibliotecas instituía o cargo de bibliotecário, porém, apenas alguns estatutos regulamentavam a função. Este "funcionário" poderia ser nomeado pela diretoria ou mesmo escolhido por voto.

Ainda com relação à instrução, havia em muitas entidades um interesse de organizar escolas - de ensino primário e técnico - explicado, em parte, pela falta de acesso de grande parte da população à educação. Em Florianópolis, na virada do século XIX para o XX, o número de analfabetos era grande, correspondendo a $60 \%$ da população ${ }^{39}$, o que demonstra que 0

\footnotetext{
${ }^{37}$ RALLE, Michel. A Festa Militante. O espaço festivo dos operários diante da identidade social (Espanha, 18501920). In: BATALHA, Cláudio H. M; SILVA, Fernando Teixeira (org.). Culturas de Classe. Campinas: Unicamp, 2004, p.30.

${ }^{38}$ Em sua pesquisa, Tânia De Lucca identificou a mesma situação; segundo a autora, esse socorro era de alto custo e difícil manutenção, como os voltados para casos de invalidez. In: DE LUCA, op cit., p.27.

${ }^{39}$ BRASIL, Ministério da Agricultura, Indústria e Comércio, Diretoria Geral de Estatística. Recenseamento do Brasil, realizado em 01 de setembro de 1920, Rio de Janeiro: Tipografia da Estatística, 1930. vol. 4, pt. I, População por sexo, estado civil e nacionalidade, p. 521; Ibidem, v. 04, pt. IV, População, p. 388/389. Disponível em: <http://biblioteca.ibge.gov.br/>. Acesso em 03 jul. 2008.
} 
acesso às 24 escolas públicas existentes na cidade era bastante dificultado ${ }^{40}$. Em termos profissionalizantes, para os trabalhadores, havia a Escola de Aprendizes Artífices, fundada em 1910, que ofertava cinco tipos de oficinas, de "mecânica, carpintaria, tipografia, encadernação e alfaiataria" $^{41}$. As vagas, porém, não chegavam a ser preenchidas, e sua abrangência, aparentemente, não era muito grande ${ }^{42}$. As camadas mais baixas da população podiam "optar" ou ser levadas à Companhia de Aprendizes Marinhos de Santa Catarina, criada em 24 de outubro de $1857^{43}$. Suas vagas não eram muito procuradas, pois "não existiam garantias para as crianças de terem um futuro certo, após serem dispensados pela marinha. Isso esclarece o fato, de apesar do prêmio (que era oferecido às famílias dos alunos matriculados), não ser grande a procura para o alistamento voluntário" ${ }^{44}$. A maioria dos jovens na faixa entre 13 e 16 anos preferia trabalhar "junto de algum mestre de ofício como aprendizes, visando garantir o aprendizado de uma profissão, que lhes proporcionasse um futuro mais estável com opção de emprego" ${ }^{\prime 45}$. Portanto, a formação dos trabalhadores não se voltava ao conhecimento das letras e sim de ofícios, dando prioridade à profissionalização técnica que trouxesse alguma garantia de futuro: "a instrução que podemos dar aos nossos filhos é geralmente a primária, que é gratuita, pois não podemos dar-lhes outra educação. Após tirarem o curso primário seguem geralmente o ofício do pai” ${ }^{46}$. Desta maneira, as associações buscavam suprir, de acordo com suas possibilidades, as demandas de seu quadro de associados.

Além do interesse em oferecer instrução e profissionalização a seus sócios, outro conjunto de incentivos deveria influenciar as entidades para que se voltassem à educação, como o fato de que, com isso, facilmente se tornavam instituições de utilidade pública, o que poderia render algum tipo de subsídio e bonificações do Estado. Nesse sentido, em 1919, foi aprovada a lei de n. $1.216^{47}$, isentando de qualquer imposto estadual as instituições onde funcionassem estabelecimentos de caridade e instrução primária gratuita. Porém, antes mesmo dessa legislação, é possível identificar subsídios estatais às associações que se propunham a dar atendimento escolar, como é o caso da União dos Trabalhadores que, em 1913, recebeu do Estado o material de uso escolar, a nomeação dos professores titulares e o pagamento dos seus

\footnotetext{
40 PEDRO, op cit., p. 49.

${ }^{41}$ COLLAÇO, op cit., p. 108.

42 Ibidem.

${ }^{43}$ Os alunos desta escola deveriam ter entre 10 e 17 anos; quando contavam idade inferior a esta faixa, as crianças deveriam ser "robustas" e com condições para atuação no mar. In: SILVA, Velôr Pereira Carpes da. Escola de Aprendizes marinheiros e Crianças desvalidas. Desterro (SC) - 1857-1889. 2002, 109 f., Dissertação. (Mestrado em Educação), Curso de Pós-Graduação em Educação, Universidade Federal de Santa Catarina, Florianópolis, 2002, p. 54-55.

${ }^{44}$ Ibidem, p. 58.

${ }^{45}$ Ibidem.

${ }^{46}$ Entrevista realizada com João dos Passos Ribeiro, carpinteiro e sócio da União Beneficente e Recreativa Operária. In: O Estado, apud COLLAÇO, op cit., p.110.

47 SANTA CATARINA, Lei n. 1.261, de 05 de setembro de 1919. Isenta de todo e qualquer imposto estadual as propriedades onde funcionam os estabelecimentos de caridade e de instrução primária gratuita e as sociedades esportivas legalmente constituídas. (CMALESC).
} 
salários $^{48}$. Em troca, além do agradecimento público, a associação enviava ao governo um relatório anual de suas atividades, oferecendo, dessa forma, uma satisfação a respeito de seus ganhos.

A Associação dos Empregados no Comércio, conhecida como ASSEC, desde sua fundação, teve como prioridade a educação, voltada de forma explicita a profissionalização e formação do trabalhador. Mas ao que tudo indica, buscou unir, na prestação desse tipo de atendimento, os seus interesses com os do Estado, pois além de oferecer seus cursos de línguas e temáticos - como de Sciencias Physicas e naturais, com aulas de física, química e história natural $^{49}$ - complementava-os com aulas de primeiras letras. Para esse curso primário, a entidade disponibilizava vagas às crianças carentes da cidade, as quais eram indicadas pelo governo do estado. Esse oferecimento era feito em número reduzido, atuando mais para conseguir benefícios do que para resolver o problema da instrução na cidade.

O Grêmio dos Empregados no Comércio, assim como a ASSEC, também tinha entre suas prioridades a instrução, trazendo como lema Instrução e Beneficência, que vinha traduzido em seu pavilhão como Proteger a instrução é engrandecer a pátria. Além de oferecer para seus sócios cursos de aperfeiçoamento profissional, como escrituração mercantil e aulas de línguas (alemão e francês), o Grêmio também mantinha cursos de primeiras letras, admitindo crianças carentes da cidade que, por seus afazeres, não pudessem freqeentar escolas públicas - sem restringir o número de vagas ${ }^{50}$. Ao contrário da ASSEC, que levou seis anos para colocar sua escola em funcionamento, o Grêmio rapidamente conseguiu se organizar, pois apenas com três meses de existência, suas aulas destinadas aos menores já contavam com 30 alunos, e o curso de escrituração mercantil com dois alunos. ${ }^{51}$

A União Operária teve, da mesma maneira, desde o início de sua atuação, o interesse em criar "escolas profissionais que cultivem educação técnica do operariado em geral, dos associados e pessoas de suas famílias" ${ }^{52}$. No planejamento estatutário, em que estruturava o funcionamento da escola, previa que, para dirigi-la, seria designado um associado pela diretoria, e que os professores trabalhariam voluntariamente. Todo o material escolar deveria ser fornecido pelo próprio aluno, "excetuando os filhos dos associados inválidos" ${ }^{53}$. Apesar de constar nos planos estatutários da entidade desde 1922, esse projeto só se efetivou após 1930.

Por fim, em relação à prestação dos socorros, havia um conjunto de atendimentos de ordem jurídica, os quais, em geral, significavam acesso a um advogado. Na maioria das

\footnotetext{
${ }^{48}$ O Dia, Florianópolis, 07 maio 1913. n. 6838. (BPESC); Ofício enviado ao governador do Estado aos cuidados do Secretário do Interior e Justiça, José Boiteux. Florianópolis, 12 mar. 1919. Cx. 11, fl. 147. (G/S. GNE D- APESC)

${ }^{49}$ O Dia, Florianópolis, 21 mar. 1905, n. 1246 (BPESC).

${ }^{50}$ O Mercantil. Florianópolis, 20 set. 1900, n. 19 (BPESC).

51 Ibidem, 17 set. 1900 , n. 17.

52 UNIÃO BENEFICENTE OPERÁRIA. Estatutos. Florianópolis: ed. Escola de Aprendizes Artífices. Florianópolis, 1922. Cap. XIII, art. 55, p. 17 (cópia cedida por Vera Regina Martins Collaço).

53 UNIÃO BENEFICENTE RECREATIVA OPERÁRIA, Florianópolis. Estatutos, 24 maio 1928. Livro 03, fl. 97 v., Cap. XV, art. 76. (CFRC).
} 
associações, o advogado era como o médico, uma peça importante, porém não indispensável, que só faria parte dos custos mensais da associação se houvesse condições financeiras para isso ou se o profissional se voluntariasse, em troca dos benefícios oferecidos pela instituição. Os serviços de um advogado eram bastante caros e nem sempre a instituição podia arcar com eles; talvez por isso, algumas instituições impunham condições na prestação de tal socorro, como provar inocência perante a assembleia geral antes da contratação. Na maioria dos casos, além de oferecer o custeio do advogado, a entendida se propunha também a manter o sócio envolvido isento dos demais pagamentos da associação até a resolução do processo.

A União dos Chauffeurs, entre todas as entidades, era a que mais priorizava esse tipo de serviço, seguido por socorros em caso de prisão e fiança, muito provavelmente por formarem os chauffeurs uma categoria exposta a problemas com a lei no exercício de sua profissão. Dessa maneira, percebe-se que a prestação de socorros em muito se relacionava ao grupo social atendido por cada instituição. Todavia, não se pode esquecer nesta análise que os socorros estavam intimamente ligados aos custos que a associação representava para seu associado tanto no processo de admissão quanto nas mensalidades e demais formas de cobranças - uma vez que a maior parte do orçamento das entidades, como demonstrado anteriormente, provinha dos sócios. Em várias associações, criavam-se fundos com a função exclusiva de financiar os socorros, provindos dos pagamentos efetuados pelos sócios.

Embora raramente as associações pluriprofissionais se destacassem entre as associações que pagavam valores mais altos em cada beneficio, eram as entidades mais completas em sua variedade, buscando atrair mais pelo número de serviços prestados do que pelo que poderiam ofertar em valores monetários. Questão que certamente tem alguma relação com a conjunção de diferentes grupos de trabalhadores associados em seu corpo.

Já as associações organizadas por ofício tinham como característica mais marcante o fato de, em grande parte dos casos, oferecer algum tipo de benefício que estivesse bem relacionado a carência e relações de trabalho próprias da categoria que pretendiam socorrer. Interessante em relação a essa informação é compreender a análise desse tipo de documentação como uma maneira de se extrair dados a respeito dos trabalhadores associados e das relações de trabalho em que estavam inseridos.

Nas associações de trabalhadores do setor público, por exemplo, percebe-se, através do que era oferecido como benefício e pela maneira de prestá-lo, uma relação bastante insipiente entre associados e entidade. Essas entidades, em geral, possuíam um conjunto muito pequeno de atendimentos, sem se destacar nos valores oferecidos, nem na qualidade e complexidade dos serviços. Primeiramente, isso se justifica pelo fato de que os trabalhadores admitidos no funcionalismo público participavam de relações bastante diversas das vividas pelos trabalhadores do setor privado, a começar pelo fato de que seu empregador e patrão era o Estado. Isso significava possuir diversas vantagens, além de algum status social, pois poucas pessoas poderiam adentrar esse ambiente de trabalho, que não estava aberto a todo e 
qualquer cidadão comum. Os concursos públicos geralmente exigiam que o candidato tivesse formação em primeiras letras, precisando responder a questões de matemática, geografia, português e de alguma outra língua - inglês, francês e alemão eram as mais comuns. Além disso, era necessário apresentar atestado de bom comportamento, fornecido por autoridade policial ou civil. Em alguns concursos, exigia-se documento que comprovasse maioridade e boa saúde. Havia ainda, dependendo da vaga à qual se concorresse, prova prática ou de conhecimentos específicos ao cargo que seria preenchido ${ }^{54}$.

As principais vantagens desse vínculo empregatício estavam relacionadas aos direitos previdenciários que esses trabalhadores possuíam, pois eram várias as leis, decretos e resoluções das três esferas de poder que deliberavam a respeito. Contava-se, por exemplo, com o direito à aposentadoria - algumas determinações tratando a respeito vigoravam desde o Império. Embora essa aposentadoria exigisse uma idade bastante avançada para a época - 70 anos - ela trazia alguma segurança, não permitindo, por exemplo, que trabalhadores considerados inválidos ficassem desamparados ${ }^{55}$.

Da mesma maneira, havia diversas possibilidades de se receber licenças, tanto para o tratamento de doenças quanto para resolução de problemas pessoais - recurso que, pela quantidade de aprovações encontradas no período em análise, aparenta ter sido bastante acessíve $^{56}$. Essas licenças poderiam ser remuneradas, e o tempo de sua duração era relativo ao pedido realizado; em alguns casos, conseguia-se até mesmo um ano de liberação remunerada. Outro grande direito era o de férias remuneradas de 15 dias, as quais foram aprovadas por decreto em 1916. No setor privado, a mesma determinação seria aprovada somente em 1925 e, ainda assim, sem ser respeitada pelos empresários, sob as vistas grossas do Estado ${ }^{57}$.

Além de todos esses direitos, os funcionários públicos contavam com a segurança de não serem demitidos de forma arbitrária e possuíam salários garantidos - que, apesar de estarem à mercê de flutuações econômicas, representavam, em média, bons ordenados. Duas condições que possuíam grande peso na época.

Outro fator que certamente influenciava nos socorros prestados por essas associações eram os chamados monte-pios (ou montepios), do qual todos os funcionários que possuíssem cargos efetivos faziam parte, obrigatoriamente. Os montepios eram entidades organizadas e gerenciadas pelo próprio Estado, com o intuito de oferecer auxílios previdenciários para seus trabalhadores, atuando como uma associação mutual através de jóias e mensalidades. Existiam desde o Império, mas segundo Tânia de Luca, somente na República é que essa prática se generalizou.

\footnotetext{
${ }^{54}$ O Dia, Florianópolis, 09 jan. 1912, n. 5.011. (BPESC).

55 DE LUCA, op cit., p. 113.

56 SANTA CATARINA. Leis, Decretos e Resoluções do Estado de SC, 1830 a 1930. passim. Lex: Coleção de Leis, Decretos e Resoluções do Estado de Santa Catarina. (CMALESC).

${ }^{57}$ DE LUCA, op cit., p. 114.
} 
O Monte-Pio Geral dos Servidores do Estado de SC foi fundado em 1851, deliberado por lei provincial ${ }^{58}$. Depois da instauração da República, foi fundado em setembro de 1909, pela Lei $825^{59}$, o Monte-Pio dos Funcionários Públicos do Estado de Santa Catarina, o qual, repetindo os moldes dos montepios nacionais, era organizado com os fins de "prover à subsistência e amparar o futuro das famílias (dos empregados do Estado), quando estes falecerem" ${ }^{60}$. Era uma instituição compulsória, que obrigava, portanto, todos os funcionários públicos efetivos a se filiarem. Os funcionários eventuais e municipais poderiam participar. No quadro nacional, os montepios foram centralizados aos poucos na estrutura do Instituto de Previdência dos Funcionários Públicos da União, fundado em 1926. No caso de Santa Catarina, isso se daria apenas em 1962, quando, através da Lei 3.138, o montepio foi reorganizado e passou a funcionar como Instituto de Previdência do Estado de Santa Catarina ${ }^{61}$.

Por terem mais direitos trabalhistas e serem obrigatoriamente parte de associações de atendimento de socorros mútuos, os funcionários públicos certamente exerciam influência nos socorros prestados por suas associações voluntárias. O interessante é que, ao contrário do que se poderia esperar, essas entidades não diversificavam seus atendimentos de forma que pudessem complementar o que os funcionários já recebiam de seus montepios. Na prática, assumiam uma forma de organização, principalmente no que diz respeito aos seus benefícios, muito parecida com a desempenhada por aqueles. Provavelmente, isso se explique principalmente pelo fato de que, por terem filiação compulsória, os montepios acabavam sendo um tipo de organização bastante conhecida entre esses trabalhadores e reconhecida como um modelo que dava certo, sendo um bom exemplo a ser seguido. Entre algumas das semelhanças, está o fato de que as associações tinham o interesse de efetuar a cobrança de suas mensalidades da mesma maneira que faziam os montepios, ou seja, através de descontos compulsórios nas folhas de pagamento. Esse objetivo é apresentado em três das associações que representavam esse grupo de trabalhadores ${ }^{62}$. Outra prática presente no montepio e reproduzida nessas entidades voluntárias era a de realizar empréstimos a juros aos seus associados, fator que as diferenciava das demais entidades, as quais não só não o faziam como também o proibiam. Novamente, as mesmas três entidades ofereciam essa possibilidade e o faziam de maneira comum entre si e semelhante à adotada pelos montepios. Esses

\footnotetext{
${ }^{58}$ SANTA CATARINA, Lei n. 567, de 23 de maio de 1851. Cria o Monte Pio Geral dos Servidores do Estado. Coleção de Leis, Decretos e Resoluções do Estado de Santa Catarina, Florianópolis. (Acervo da Biblioteca do Instituto de Previdência do Estado de Santa Catarina. Doravante BIPESC).

${ }^{59}$ SANTA CATARINA, Lei n. 825, de 15 de setembro de 1909. Criando o Montepio dos funcionários do Estado. Cópia reproduzida do Instituto Histórico e Geográfico de Santa Catarina (BIPESC).

${ }^{60}$ Ibidem.

${ }^{61}$ SANTA CATARINA, Lei n. 3.138, de 11 de dezembro de 1962.

${ }^{62}$ CAIXA BENEFICENTE DOS EMPREGADOS DO DISTRITO TELEGRÁFICO DE SANTA CATARINA, Florianópolis. Estatutos, 11 mar. 1914. Livro 02, fl. 45. Cap. VIII, art. 21. (CFRC); ASSOCIAÇÃO BENEFICENTE DOS GUARDAS DAS ALFÂNDEGAS, Florianópolis. Estatutos, 02 abr. 1914. Livro 02, fl. 49. Cap. II, art. 32. (CFRC); SOCIEDADE BENEFICENTE DOS EMPREGADOS POSTAIS DE SANTA CATARINA, Florianópolis. Estatutos, 09 jun. 1926. Livro 03, fl. 61. Cap. IX, art. 33. (CFRC).
} 
empréstimos sempre exigiam algum tipo de garantia (a qual poderia se dar através de desconto no pagamento do pecúlio em caso de falecimento ou mesmo por notas promissórias), assim como exigiam que o solicitante fosse empregado público, de preferência, da repartição que a entidade representava e, caso não o fosse, que apresentasse fiador aceito pela diretoria da instituição. Os juros variavam bastante. Possivelmente, o fato de esses trabalhadores terem cargos seguros - uma vez que eram concursados e efetivados - dava a suas associações uma sensação menor de risco.

O único socorro prestado por essas associações que não estava entre os oferecidos pelos montepios dizia respeito a estes, uma vez que se pautava na intenção de várias entidades de atuar na organização e agilização da documentação necessária ao recebimento dos pecúlios oferecidos em caso de falecimento. Para isso, organizavam comissões responsáveis e efetuavam adiantamentos financeiros que deveriam ser restituídos posteriormente.

Um fator comum a essas associações de funcionários públicos, perceptível nos socorros que prestavam, era a ausência de preocupação em se tornar, para seus membros, mais do que simples prestadoras de serviços, uma vez que não apresentavam nenhum tipo de atuação que construísse ambientes que pudessem tornar a entidade frequentada e nos quais se desenvolvessem relações identitárias, possuindo seus estatutos redações extremamente enxutas e eficientes num olhar administrativo.

Algumas associações de ofício do setor privado agiam da mesma maneira, desenvolvendo estatutos objetivos e prestando socorros comuns, que pouco expunham a respeito daqueles que representavam. Entre elas, a Congregação dos Náuticos e Pescadores de Santa Catarina, a Liga do Magistério e a União Beneficente dos Padeiros, entidades que cobravam pouco de seus sócios e, em troca, ofereciam também pouco, sem nenhum tipo de atrativo voltado a especificidades de suas categorias. Possivelmente, essas entidades, ao se formarem, acreditaram que atrairiam os trabalhadores de suas respectivas categorias simplesmente pelo fato de terem a intenção de representá-los, ou baseando-se no poder de atração e identificação que seus fundadores e iniciadores possuíam.

Pensando nessas associações como participantes de um mercado previdenciário de grande concorrência, assumir esse tipo de estratégia (ou justamente não assumir estratégia nenhuma) poderia ser muito perigoso para a manutenção de suas existências. No caso das duas associações citadas primeiramente - Congregação dos Náuticos e Pescadores e Liga do Magistério - aparentemente não bastou o fato de serem de ofício, pois pelos registros analisados, ambas parecem ter tido existência curta, o que, na maioria dos casos, se dava pelo fato de não conseguirem agregar um número suficiente de pessoas que as mantivessem. Por outro lado, as associações que possuíram uma atuação mais longa e expressiva nesse conjunto de entidades de trabalhadores do setor privado apresentavam, ao menos, algum diferencial em seus serviços que, na maioria dos casos, muito diz a respeito dos trabalhadores que pretendiam atrair. 
Portanto, ao elaborar um conjunto de socorros como prioridade nos atendimentos compreendendo que estes deveriam estar de acordo com os recursos disponíveis ou em vista a associação acabava incluindo e excluindo (ou atraindo e afastando) pessoas. Esse processo poderia se dar por planejamento, com os fundadores da entidade elaborando estratégia de diferenciação e atração de novos associados, de acordo com um mercado em disputa ou, independentemente de intenções, pelo fato de que os fundadores da associação também eram trabalhadores e imprimiam às suas entidades suas próprias necessidades e anseios, atraindo, assim, outros trabalhadores que compartilhavam das mesmas aspirações.

A forma como cada entidade administrava suas despesas e receitas era bastante variada e tinha completa relação com as pretensões assumidas. Assim, entidades que priorizavam cobranças acessíveis, provavelmente, pretendiam atrair muitas pessoas e, consequentemente, formar um grupo grande de membros. Esse tipo de decisão poderia ocasionar - ao menos, a princípio - limitações nos oferecimentos dos socorros, tanto na variedade quanto na qualidade monetária de cada um deles. Uma saída muitas vezes utilizada era restringir o atendimento a socorros mais básicos - como o atendimento voltado a saúde e funeral -, disponibilizando valores medianos, o que poderia ser melhorado com o passar dos anos e o crescimento da associação. Por outro lado, havia a possibilidade de se basear a administração financeira numa cobrança de valores altos dos associados, oferecendo em troca um amplo leque de serviços ou atendimentos. Outra possibilidade era a prestação de socorros mais especializados.

As formas de administrar as finanças da associação em relação aos benefícios poderiam variar ao longo dos anos, em função da experiência que as associações acumulavam, mas em geral, o que se observa na análise das associações florianopolitanas é que as estratégias que determinavam a priori acabavam por ser seguidas, pois definiam características de atuação e formação da entidade, principalmente em relação ao seu público, uma vez que, mesmo não sendo planejadas, essas estratégias eram atrativos de filiação e manutenção do corpo social, o qual permitia a existência material das associações.

A "escolha" do público que se pretendia ter na entidade era, portanto, definida estatutariamente, não somente nos artigos que discutiam quem poderia se associar, mas também nos custos que a associação representava e nos socorros que prestava - pois para se associar, um trabalhador certamente realizava (mesmo que inconscientemente) uma mediação entre custo e beneficio, avaliando os gastos que seriam despendidos e o que se ganharia em troca. Nessa avaliação, contariam tanto os objetivos centrais da associação, como o oferecimento dos socorros, quanto os periféricos, que passavam pelo espaço de sociabilidade interna constituída (importando relações pessoais e políticas), as ofertas de inclusão e atuação em relação ao mercado de trabalho e, até mesmo, a inserção social e o tamanho que a entidade conquistara, o qual simbolizaria, para o futuro membro, um espaço de reconhecimento social e de construção de sua dignidade enquanto trabalhador. Portanto, diversos fatores convergiam no processo de filiação, numa dialética que se torna impossível definir qual possuía maior 
importância ou mesmo prioridade, pois todos se relacionavam e, de alguma maneira, atuavam uns em relação aos outros. Os fatores materiais - quanto se cobrava e quanto se oferecia interferiam e eram influenciados pelos fatores subjetivos - baseados nas relações entre pessoas.

Recebido em 10/05/2012

Aceito para publicação em 15/06/2012 